\title{
Tropomyosin-related receptor kinase B at the invasive front and tumour cell dedifferentiation in gastric cancer
}

\author{
K Tanaka*,1 ${ }^{*}$ T Shimura ${ }^{1}$, T Kitajima ${ }^{1}$, S Kondo ${ }^{1}$, S Ide ${ }^{1}$, Y Okugawa ${ }^{1}$, S Saigusa ${ }^{1}$, Y Toiyama ${ }^{1}$, Y Inoue ${ }^{1}$, T Araki $^{1}$, \\ K Uchida ${ }^{1}$, Y Mohri $^{1}$ and M Kusunoki ${ }^{1}$ \\ ${ }^{1}$ Department of Gastrointestinal and Pediatric Surgery, Mie University Graduate School of Medicine, 2-174 Edobashi, Tsu, Mie \\ 514-8507, Japan
}

Background: Tropomyosin-related receptor kinase B (TrkB) promotes proliferation and invasion, relating to poor prognosis of various malignancies. We examined the role of TrkB at the invasive front of gastric cancer (GC) and its association with tumour cell dedifferentiation and tumour budding.

Methods: Immunoreactive TrkB was evaluated at the tumour centre and margin using whole-tissue sections of 320 GC patients. Tumour cell dedifferentiation was defined as higher histologic grade at the tumour margin than the surface or tumour centre. Tumour budding was also scored on cytokeratin-stained sections.

Results: Sixty-five patients (20\%) showed higher TrkB expression at the invasive front (TrkB expression was higher at the tumour margin than tumour centre). It was significantly associated with several aggressive phenotypes in the full cohort $(n=320)$. It showed a prognostic significance in test subgroup $(n=98)$ and was identified as an independent prognostic factor $(H R=2.09$; $95 \% \mathrm{Cl}: 1.26-3.53)$ by multivariate analysis in validation subgroup $(n=222)$. Twenty-one patients showed tumour cell dedifferentiation. In predominantly differentiated tumour, higher TrkB at the invasive front was significantly associated with tumour budding rather than tumour cell dedifferentiation.

Conclusions: Assessment of immunoreactive TrkB at the invasive front by whole-tissue sections provides prognostic information for GC patients.

Tropomyosin-related receptor kinase $\mathrm{B}(\operatorname{TrkB})$ is a tyrosine kinase receptor for brain-derived neutrophic factor (BDNF), which triggers several intracellular signals (Barbacid, 1994). An overexpression of $\operatorname{TrkB}$ has been reported in various human malignancies and demonstrated its association with tumour cell proliferation, invasion, metastasis, and poor prognosis (Thiele et al, 2009; Li et al, 2011; Lee et al, 2012; Sasahira et al, 2013). TrkB has been also involved in resistance to anoikis (a form of detachment-induced apoptosis), implying its metastatic property (Douma et al, 2004).

The epithelial-to-mesenchymal transition (EMT) is a process in which cells undergo a switch from an epithelial phenotype to a mesenchymal phenotype. The epithelial cells acquire an enhanced motility and show a fibroblast-like morphology. Increased evidence has demonstrated that EMT was associated with cancer invasion, metastasis, and consequent poor prognosis. Association between TrkB and EMT has also been demonstrated in several human malignancies (Kupferman et al, 2010; Smit and Peeper, 2011).

These lines of evidence suggest that TrkB may be one of the representative molecules that reveal an association between the molecular change (overexpression of $\operatorname{TrkB}$ ) and the morphological change (EMT).

The term 'dedifferentiation' has been reported as a progression of cells towards a less differentiated state with no longer the 
original line of differentiation (Dahlin and Beabout, 1971). Recently, the term 'high-grade transformation' has been introduced as a state in which the dedifferentiated component maintains some features of the original tumour (Seethala et al, 2007).

Gastric cancer (GC) is the fourth most common malignancy and the second leading cause of cancer-related death in the world. Poorly differentiated GC such as poorly differentiated tubular adenocarcinoma, signet ring cell carcinoma, and mucinous adenocarcinoma has been shown to be associated with more aggressive phenotype and poor prognosis (Choi et al, 2009; Piessen et al, 2009). On the other hand, GC frequently shows marked histological heterogeneity and co-existence of several histological components within the tumour. A certain number of GCs with such mixed histology show both low or intermediate grade (well/moderately differentiated) at the surface to the centre and a high grade (poorly differentiated) at the invasive front of the tumour. The characteristics of GCs with 'dedifferentiated tumour cells at the invasive front' have not yet been fully analysed.

Tumour budding, which is defined as an isolated single cancer cell or tumour cluster of fewer than five cancer cells without glandular formation, has been demonstrated to be associated with tumour invasion, metastasis, and poor prognosis in several human malignancies (Lugli et al, 2012). Tumour budding has not been fully characterised in GC, although the prognostic significance of tumour budding was reported in oesophageal and gastrooesophageal junction cancers (Brown et al, 2010).

Previously, we reported the association of TrkB with tumour progression and patients' prognosis in GC (Tanaka et al, 2009a), its association with chemotherapy resistance in oesophageal cancer (Tanaka et al, 2009b), and its involvement in EMT in colorectal cancer (Fujikawa et al, 2012). More recently, we have demonstrated that the immunoreactive $\mathrm{BDNF} / \mathrm{TrkB}$ co-expression at the invasive front was significantly associated with histological intestinal type and lymph node metastasis in 150 patients with GC (Okugawa et al, 2013).

In this study, we re-evaluated the immunoreactive TrkB expression at the invasive front in a larger series of $320 \mathrm{GC}$ patients and clarified its clinical and prognostic significance. We also examined the association of $\operatorname{TrkB}$ expression with tumour cell dedifferentiation and tumour budding.

\section{MATERIALS AND METHODS}

Patients and specimens. Three hundred and sixty patients with GC, who were resected at the Department of Gastrointestinal and Pediatric Surgery of Mie University Graduate School of Medicine from 2000 to 2011, were included in this study.

Patients with incomplete clinical data $(n=8)$ or inadequate follow-up $(n=17)$ were excluded. Specimens with insufficient tumour $(n=3)$ or no residual tumour $(n=12)$ were excluded from further analysis. Finally, a total of 320 specimens were analysed as the full cohort. Patient and tumour characteristics are shown in Table 1. Our retrospective study adheres to the REMARK criteria (McShane et al, 2005).

All patients had histologically confirmed adenocarcinoma of the stomach. The median age was 68 years (range: $18-90$ years). The median follow-up time was 25.9 months (range: 1.4-124.5). A total of 70 patients died of GC-related causes during this period. Postoperative adjuvant chemotherapy was given to 111 patients with pathological lymph node metastasis. Palliative chemotherapy was given to 50 patients with stage IV disease.

All resected specimens were fixed in 10\% formalin, embedded in paraffin, and stained with haematoxylin and eosin (H\&E). All histopathological data were reviewed from the corresponding H\&E-stained slides.
Staging was based on clinical assessment and histopathological analysis by the International Union Against Cancer (UICC) TNM staging system. Written informed consent of all patients was obtained according to the local ethics guidelines. The study was approved by the Institutional Review Board.

Histological classification. According to the World Health Organization classification, the four predominant histological types of gastric adenocarcinoma are tubular adenocarcinoma, papillary adenocarcinoma, mucinous adenocarcinoma, and signet ring cell carcinoma (Bosman et al, 2010).

By contrast, the Japanese classification of gastric carcinoma (3rd English edition) categorises gastric adenocarcinomas into two groups: differentiated and undifferentiated. The differentiated adenocarcinoma consists of well-, moderately differentiated, and papillary adenocarcinoma. The undifferentiated adenocarcinoma consists of poorly differentiated adenocarcinoma and signet ring cell carcinoma. Mucinous adenocarcinoma is regarded as either a differentiated or undifferentiated type, depending on the predominant components (Japanese Gastric Cancer Association, 2011).

In this study, the histology for GC was classified into three types based on the predominant histology: well-differentiated adenocarcinoma (well-differentiated tubular adenocarcinoma and papillary adenocarcinoma), moderately differentiated adenocarcinoma, and poorly differentiated adenocarcinoma (poorly differentiated tubular adenocarcinoma, signet ring cell carcinoma, and mucinous adenocarcinoma).

In addition, the following histological classifications were also used. Differentiated and undifferentiated adenocarcinoma by the Japanese classification, and intestinal type (papillary, tubular, and mucinous adenocarcinoma) and diffuse type (signet ring cell ca. and poorly differentiated tubular adenocarcinoma) by the Lauren's classification (Lauren, 1965).

Immunohistochemistry for TrkB and cytokeratin. Paraffinembedded tissue sections $(3 \mu \mathrm{m})$ were subjected to immunohistochemistry. Whole-tissue sections were made and used to assess the difference in histology and $\operatorname{TrkB}$ expresion between the superficial or centre of the tumour and the invasive front of the tumour. Cytokeratin immunostaining was used to facilitate the visualisation of tumour buddig at the invasive front.

Sections were deparaffinised by xylene, rehydrated in graded concentrations of ethanol, and were pretreated in an autoclave at $121^{\circ} \mathrm{C}$ for $15 \mathrm{~min}$ in $10 \mathrm{~mm}$ citrate buffer ( $\mathrm{pH} \mathrm{6.0)}$ ). Endogenous peroxidase activity was blocked by incubation for $30 \mathrm{~min}$ with $0.3 \%$ hydrogen peroxide in methanol. Non-specific binding sites were blocked in $1 \mathrm{moll}^{-1}$ phosphate-buffered saline (PBS) with $10 \%$ normal goat serum and an Avidin/Biotin Blocking Kit (Vector Laboratories, Burlingame, CA, USA). The sections were then incubated with primary mouse monoclonal antibody against TrkB ( $1: 100$; R\&D Systems, Foster City, CA, USA) in PBS containing $1 \%$ bovine serum albumin (BSA) for $16 \mathrm{~h}$ at $4{ }^{\circ} \mathrm{C}$. The other sections were also incubated with primary mouse monoclonal antibody against cytokeratin clone AE1/AE3 (Dako Cytomation, Glostrup, Denmark) in PBS containing 1\% BSA for $60 \mathrm{~min}$ at room temperature. After washing with PBS, sections were loaded with secondary antibody coupled with peroxidase-conjugated polymers (EnVision + System, DakoCytomation A/S) for $30 \mathrm{~min}$. Subsequently, the primary antibodies were detected by using AEC Substrate Chromogen (DakoCytomation A/S) according to the instructions of the manufacturer. The sections were counterstained with Mayer's haematoxylin, dehydrated in graded concentrations of ethanol, and mounted. Negative control tissue sections were prepared by omitting the primary antibody.

Evaluation of immunoreactive TrkB protein. In this study, the 'tumour margin' was defined as all regions of the tumour border 


\begin{tabular}{|c|c|c|}
\hline \multirow[b]{2}{*}{ Variables } & \multicolumn{2}{|c|}{ Patients } \\
\hline & Number & $\%$ \\
\hline \multicolumn{3}{|l|}{ Gender } \\
\hline $\begin{array}{l}\text { Male } \\
\text { Female }\end{array}$ & $\begin{array}{r}231 \\
89\end{array}$ & $\begin{array}{l}72 \\
28\end{array}$ \\
\hline \multicolumn{3}{|l|}{ Age (years) } \\
\hline $\begin{array}{l}\leqslant 68 \\
>68\end{array}$ & $\begin{array}{l}165 \\
155\end{array}$ & $\begin{array}{l}52 \\
48\end{array}$ \\
\hline \multicolumn{3}{|l|}{ Tumour size (mm) } \\
\hline $\begin{array}{l}\leqslant 45 \\
>45\end{array}$ & $\begin{array}{l}156 \\
164\end{array}$ & $\begin{array}{l}49 \\
51\end{array}$ \\
\hline \multicolumn{3}{|l|}{ Macroscopic type } \\
\hline $\begin{array}{l}0 \\
1 \\
2 \\
3 \\
4\end{array}$ & $\begin{array}{r}107 \\
19 \\
67 \\
106 \\
21\end{array}$ & $\begin{array}{r}33 \\
6 \\
21 \\
33 \\
7\end{array}$ \\
\hline \multicolumn{3}{|l|}{ Histology 1} \\
\hline $\begin{array}{l}\text { Well-diff. adenoca. } \\
\text { Moderately diff. adenoca. } \\
\text { Poorly diff. adenoca. } \\
\text { Signet ring cell ca. } \\
\text { Mucinous adeno ca. }\end{array}$ & $\begin{array}{r}62 \\
91 \\
109 \\
44 \\
14\end{array}$ & $\begin{array}{r}19 \\
28 \\
34 \\
14 \\
5\end{array}$ \\
\hline \multicolumn{3}{|c|}{ Histology 2 (Japanese classification) } \\
\hline $\begin{array}{l}\text { Differentiated } \\
\text { Undifferentiated }\end{array}$ & $\begin{array}{l}153 \\
167\end{array}$ & $\begin{array}{l}48 \\
52\end{array}$ \\
\hline \multicolumn{3}{|c|}{ Histology 3 (Lauren's classification) } \\
\hline $\begin{array}{l}\text { Intestinal type } \\
\text { Diffuse type }\end{array}$ & $\begin{array}{l}161 \\
159\end{array}$ & $\begin{array}{l}50 \\
50\end{array}$ \\
\hline \multicolumn{3}{|c|}{ Lymphovascular invasion } \\
\hline $\begin{array}{l}\text { Absent } \\
\text { Present }\end{array}$ & $\begin{array}{r}78 \\
242\end{array}$ & $\begin{array}{l}24 \\
76\end{array}$ \\
\hline \multicolumn{3}{|l|}{ pT } \\
\hline $\begin{array}{l}\text { T1 } \\
\text { T2 } \\
\text { T3 } \\
\text { T4 }\end{array}$ & $\begin{array}{r}107 \\
37 \\
68 \\
108\end{array}$ & $\begin{array}{l}33 \\
11 \\
21 \\
35\end{array}$ \\
\hline \multicolumn{3}{|l|}{$\mathrm{pN}$} \\
\hline $\begin{array}{l}\text { Absent } \\
\text { Present }\end{array}$ & $\begin{array}{l}158 \\
162\end{array}$ & $\begin{array}{l}49 \\
51\end{array}$ \\
\hline \multicolumn{3}{|l|}{ Liver metastasis } \\
\hline $\begin{array}{l}\text { Absent } \\
\text { Present }\end{array}$ & $\begin{array}{r}303 \\
17\end{array}$ & $\begin{array}{r}94 \\
6\end{array}$ \\
\hline \multicolumn{3}{|l|}{ Peritoneal metastasis } \\
\hline $\begin{array}{l}\text { Absent } \\
\text { Present }\end{array}$ & $\begin{array}{r}292 \\
28\end{array}$ & $\begin{array}{r}91 \\
9\end{array}$ \\
\hline \multicolumn{3}{|c|}{ Other distant metastasis } \\
\hline $\begin{array}{l}\text { Absent } \\
\text { Present }\end{array}$ & $\begin{array}{r}303 \\
17\end{array}$ & $\begin{array}{r}95 \\
5\end{array}$ \\
\hline
\end{tabular}

Table 1. (Continued)

\begin{tabular}{|l|c|c|}
\cline { 2 - 2 } \multicolumn{2}{|c|}{} & \multicolumn{2}{c|}{ Patients } \\
\hline Variables & Number & $\%$ \\
\hline pStage & 125 & 39 \\
\hline 1 & 64 & 20 \\
2 & 74 & 23 \\
3 & 57 & 18 \\
4 & \\
\hline \multirow{2}{*}{ Abbreviations: adenoca. = adenocarcinoma; ca. = carcinoma; diff. = differentiated; pN $=$} \\
pathological nodal stage; pStage = pathological stage; $\mathrm{pT}=$ pathological tumour stage. \\
\hline
\end{tabular}

area between the primary tumour lesion and its surrounding interstitium. It was regarded as the area $<0.5 \mathrm{~mm}$ wide in tumour periphery of the interface between tumour and stroma. In contrast, the 'tumour centre' was regarded as the area from the luminal surface to the tumour margin, excluding the necrotic areas as described previously (Alpízar-Alpízar et al, 2012).

Two independent researchers with no prior knowledge of clinical or pathological parameters evaluated TrkB expression on the basis of the proportion of TrkB-positive tumour cells to total tumour cells, because staining intensity seems to be subjective, less reproducible, and affected by the storage time (Zlobec et al, 2007).

For the evaluation of $\operatorname{TrkB}$ expression, the whole tissue sections were observed at medium $(\times 40)$ and high magnification $(\times 200)$. TrkB-positive tumour cells with nuclear or cytoplasmic immunostaining were counted in high-power field $(\mathrm{HPF} ; \times 200)$ of five randomly selected areas in both tumour centre and margin. The percentage of TrkB-positive tumour cells per HPF was scored semi-quantitatively in $10 \%$ intervals $(0 \%, 10 \%, \ldots$, $100 \%)$ (Karamitopoulou et al, 2011). The mean percentage was determined by averaging the counts of five HPFs and was regarded as TrkB expression at the tumour centre or margin in each patient.

The few discrepancies were resolved using a multihead microscope, and then consensus was reached for each slide. For survival analysis, the optimum cut-off value of mean percentage of TrkB-positive tumour cells in both tumour centre and margin was determined by receiver operator characteristic (ROC) analysis.

Definition of higher TrkB expression at the invasive front. After evaluation of TrkB expression in both tumour centre and margin, mean percentage of TrkB-positive tumour cells was compared between tumour centre and tumour margin. When mean percentage of TrkB expression in tumour margin was larger than that in tumour centre, the case was defined as the presence of higher TrkB expression at the invasive front. When there was no difference in mean percentage of TrkB expression between tumour centre and margin, the case was defined as the absence of higher TrkB expression at the invasive front.

Evaluation of tumour cell dedifferentiation at the invasive front. According to the tumour grading systems (Sobin et al, 2009), well, moderately, and pooly differentiated tumour are assigned as low, intermediate, and high grade, respectively. Gastric cancer demonstrates marked histological heterogeneity at both architectural and cytologic level, and frequently shows co-existence of several histologic elements. Dahlin and Beabout (1971) reported the term 'dedifferentiation', which is the progression of cells towards a less differentiated state with no longer the original line of differentiation. Recently, Seethala et al (2007) introduced the term 'high-grade transformation', which is a state that the 
dedifferentiated component maintains some features of the original tumour.

Among GC with co-existence of several histologic elements, one form of GC with mixed histology exists, which shows both low or intermediate grade (well/moderately differentiated) at the surface to the centre and a high grade (poorly differentiated) at the invasive front of the tumour.

In this study, we defined dedifferentiated GCs as the tumours with higher histologic grade at the invasive front than that at the surface or the centre of tumour. Therefore, we evaluated tumour cell dedifferentiation in well- or moderately differentiated tumours.

Evaluation of tumour budding stained by cytokeratin at the tumour invasive front. Tumour budding is defined as an isolated single tumour cell or a tumour cluster of fewer than five tumour cells with no glandular formation that were detached from the primary tumour (Lugli et al, 2012).

Undifferentiated tumours, including signet ring cell carcinoma, poorly differentiated, or mucinous adenocarcinoma, can form no or very few glandular structures. Their growth patterns show irregular trabaculae, lace-like cell clusters, or scattered single cells (Bosman et al, 2010; Japanese Gastric Cancer Association, 2011).

In this study, we excluded undifferentiated adenocarcinoma for assessment of tumour budding in GC because it is difficult to discriminate between tumour budding and growth phenotype of undifferentiated tumour itself.

Although several methods for the assessment of tumour budding has been reported (Horcic et al, 2013), we used the scoring method proposed by Karamitopoulou et al (2013) with minor modification. In brief, the cytokeratin-stained whole tissue sections were observed at low magnification $(\times 10)$ for identifying the tumour margin area with the highest density of tumour budding. The number of tumour budding was counted in the HPF of the tumour margin with the highest density of tumour budding using a $\times 40$ magnification. The average number of tumour budding were determined across at least three HPFs.
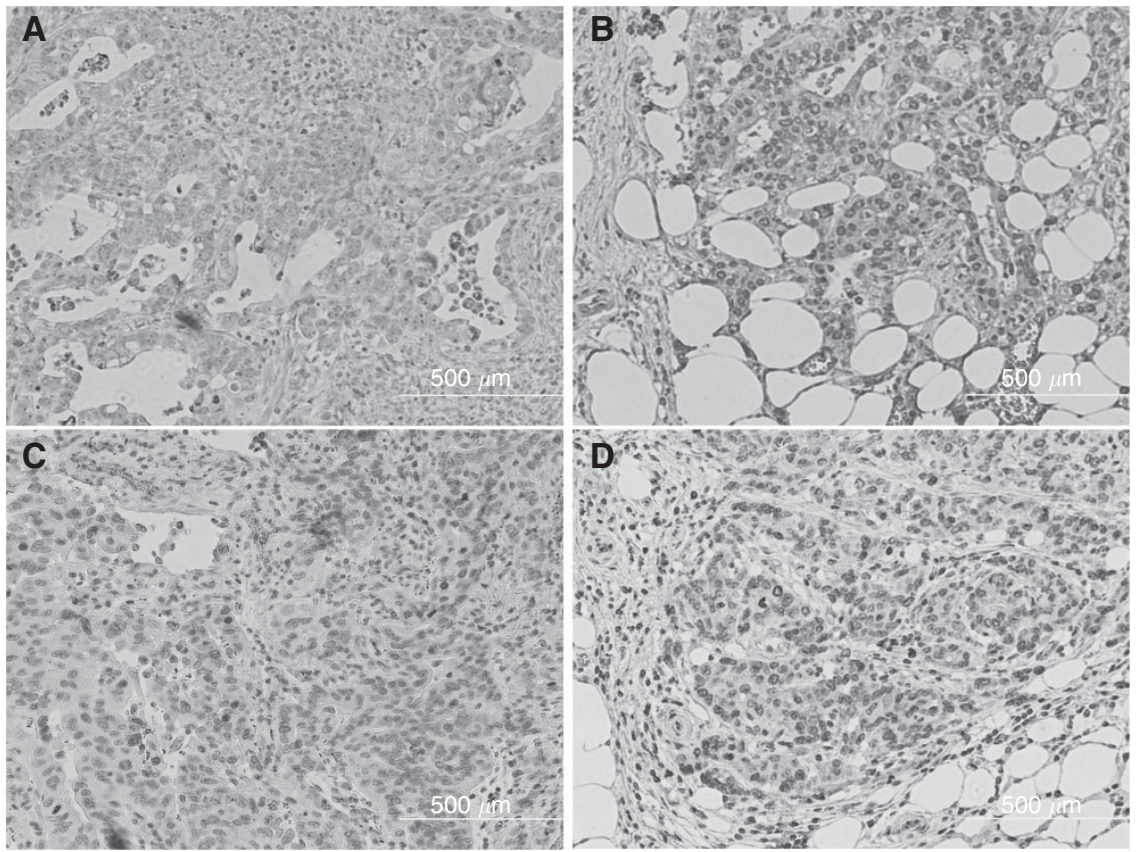

Figure 1. TrkB expression at the tumour centre and tumour margin. The representative images from two cases with higher TrkB at the invasive front were shown. Figures ( $\mathbf{A}$ and $\mathbf{B})$ or ( $\mathbf{C}$ and $\mathbf{D})$ were from the same patient. TrkB expression at the tumour margin ( $\mathbf{B}$ and $\mathbf{D})$ was higher than that of the tumour centre $(\mathbf{A}$ and $\mathbf{C})$ in the patient with both differentiated adenocarcinoma histology $(\mathbf{A}$ and $\mathbf{B})$ and undifferentiated adenocarcinoma histology (C and $\mathbf{D})$. 
Table 2. Associations of TrkB expression with clinicopathological variables $(n=320)$

\begin{tabular}{|c|c|c|c|c|c|c|c|c|c|c|}
\hline \multirow[b]{2}{*}{ Variables } & \multirow[b]{2}{*}{ Number } & \multicolumn{2}{|c|}{$\begin{array}{c}\text { TrkB at the tumour } \\
\text { centre }\end{array}$} & \multirow[b]{2}{*}{$P$-value } & \multicolumn{2}{|c|}{$\begin{array}{c}\text { TrkB at the tumour } \\
\text { margin }\end{array}$} & \multirow[b]{2}{*}{$P$-value } & \multicolumn{2}{|c|}{$\begin{array}{l}\text { Higher TrkB at the } \\
\text { invasive front }\end{array}$} & \multirow[b]{2}{*}{$P$-value } \\
\hline & & Low & High & & Low & High & & Negative & Positive & \\
\hline \multicolumn{11}{|l|}{ Gender } \\
\hline Male & 231 & 181 & 50 & & 193 & 38 & & 181 & 50 & \\
\hline remale & 09 & & & 0.95 & & & 0.23 & & & 0.33 \\
\hline \multicolumn{11}{|l|}{ Age } \\
\hline$\leqslant 68$ & 165 & 136 & 29 & & 148 & 17 & & 138 & 27 & \\
\hline$>68$ & 155 & 117 & 38 & 0.13 & 124 & 31 & 0.01 & 117 & 38 & 0.07 \\
\hline \multicolumn{11}{|l|}{ Tumour size (mm) } \\
\hline$\leqslant 45$ & 156 & 136 & 21 & & 138 & 18 & & 138 & 18 & \\
\hline$>45$ & 164 & 118 & 46 & $<0.01$ & 134 & 30 & 0.09 & 117 & 47 & $<0.01$ \\
\hline \multicolumn{11}{|l|}{ Macroscopic type } \\
\hline 0 & 107 & 98 & 9 & & 103 & 4 & & 106 & 1 & \\
\hline 1 & 19 & 10 & 9 & & 12 & 7 & & 12 & 7 & \\
\hline 2 & 67 & 45 & 22 & & 56 & 11 & & 55 & 12 & \\
\hline 3 & 106 & 86 & 20 & & 87 & 19 & & 69 & 37 & \\
\hline 4 & 21 & 14 & 7 & $<0.01$ & 14 & 7 & $<0.01$ & 13 & 8 & $<0.01$ \\
\hline \multicolumn{11}{|l|}{ Histology 1} \\
\hline Well-diff. adenoca. & 62 & 44 & 18 & & 53 & 9 & & 56 & 6 & \\
\hline Moderately diff. adenoca. & 91 & 66 & 25 & & 70 & 21 & & 63 & 28 & \\
\hline Poorly diff. adenoca. & 109 & 92 & 17 & & 94 & 15 & & 82 & 27 & \\
\hline Signet ring cell ca. & 44 & 39 & 5 & & 41 & 3 & & 42 & 2 & \\
\hline Mucinous adeno ca. & 14 & 12 & 2 & 0.04 & 14 & 0 & 0.02 & 12 & 2 & $<0.01$ \\
\hline \multicolumn{11}{|c|}{ Histology 2 (Japanese classification) } \\
\hline Differentiated & 153 & 110 & 43 & & 123 & 30 & & 119 & 34 & \\
\hline Undifferentiated & 167 & 143 & 24 & $<0.01$ & 149 & 18 & 0.03 & 136 & 31 & 0.42 \\
\hline \multicolumn{11}{|c|}{ Histology 3 (Lauren's classification) } \\
\hline Intestinal type & 161 & 116 & 45 & & 131 & 30 & & 126 & 35 & \\
\hline Diffuse type & 159 & 137 & 22 & $<0.01$ & 141 & 18 & 0.06 & 129 & 30 & 0.52 \\
\hline \multicolumn{11}{|l|}{ Lymphovascular invasion } \\
\hline Absent & 78 & 71 & 7 & & 75 & 3 & & 76 & 2 & \\
\hline Present & 242 & 182 & 60 & $<0.01$ & 197 & 48 & $<0.01$ & 179 & 63 & $<0.01$ \\
\hline \multicolumn{11}{|l|}{ pT } \\
\hline T1 & 107 & 93 & 14 & & 102 & 5 & & 105 & 2 & \\
\hline $\mathrm{T} 2$ & 37 & 31 & 6 & & 34 & 3 & & 35 & 2 & \\
\hline T3 & 68 & 49 & 19 & & 55 & 12 & & 53 & 15 & \\
\hline T4 & 108 & 80 & 28 & 0.03 & 81 & 27 & $<0.01$ & 62 & 46 & $<0.01$ \\
\hline \multicolumn{11}{|l|}{$\mathrm{pN}$} \\
\hline Absent & 158 & 134 & 24 & & 145 & 13 & & 144 & 14 & \\
\hline Present & 162 & 119 & 43 & 0.01 & 127 & 35 & $<0.01$ & 111 & 51 & $<0.01$ \\
\hline \multicolumn{11}{|l|}{ Liver metastasis } \\
\hline Absent & 303 & 242 & 61 & & 262 & 41 & & 247 & 56 & \\
\hline Present & 17 & 11 & 6 & 0.16 & 10 & 7 & $<0.01$ & 8 & 9 & $<0.01$ \\
\hline \multicolumn{11}{|l|}{ Peritoneal metastasis } \\
\hline Absent & 292 & 233 & 59 & & 255 & 37 & & 241 & 51 & \\
\hline Present & 28 & 20 & 8 & 0.32 & 17 & 11 & $<0.01$ & 14 & 14 & $<0.01$ \\
\hline
\end{tabular}




\begin{tabular}{|c|c|c|c|c|c|c|c|c|c|c|}
\hline \multirow[b]{2}{*}{ Variables } & \multirow[b]{2}{*}{ Number } & \multicolumn{2}{|c|}{$\begin{array}{l}\text { TrkB at the tumour } \\
\text { centre }\end{array}$} & \multirow[b]{2}{*}{$P$-value } & \multicolumn{2}{|c|}{$\begin{array}{l}\text { TrkB at the tumour } \\
\text { margin }\end{array}$} & \multicolumn{3}{|c|}{$\begin{array}{l}\text { Higher TrkB at the } \\
\text { invasive front }\end{array}$} & \multirow[b]{2}{*}{$P$-value } \\
\hline & & Low & High & & Low & High & $P$-value & Negative & Positive & \\
\hline \multicolumn{11}{|c|}{ Other distant metastasis } \\
\hline $\begin{array}{l}\text { Absent } \\
\text { Present }\end{array}$ & $\begin{array}{r}303 \\
17\end{array}$ & $\begin{array}{r}245 \\
8\end{array}$ & $\begin{array}{r}58 \\
9\end{array}$ & $<0.01$ & $\begin{array}{r}262 \\
10\end{array}$ & $\begin{array}{r}41 \\
7\end{array}$ & $<0.01$ & $\begin{array}{r}246 \\
9\end{array}$ & $\begin{array}{r}57 \\
8\end{array}$ & 0.01 \\
\hline \multicolumn{11}{|l|}{ pStage } \\
\hline $\begin{array}{l}1 \\
2 \\
3 \\
4\end{array}$ & $\begin{array}{r}125 \\
64 \\
74 \\
57\end{array}$ & $\begin{array}{r}110 \\
49 \\
55 \\
39\end{array}$ & $\begin{array}{l}15 \\
15 \\
19 \\
18\end{array}$ & $<0.01$ & $\begin{array}{r}118 \\
56 \\
60 \\
38\end{array}$ & $\begin{array}{r}7 \\
8 \\
14 \\
19\end{array}$ & $<0.01$ & $\begin{array}{r}122 \\
55 \\
50 \\
28\end{array}$ & $\begin{array}{r}3 \\
9 \\
24 \\
29\end{array}$ & $<0.01$ \\
\hline
\end{tabular}

the same patient. TrkB expression at the tumour margin (Figure $1 \mathrm{~B}$ and $\mathrm{D}$ ) was higher than that of the tumour centre (Figure $1 \mathrm{~A}$ and $\mathrm{C}$ ) in the patient with differentiated adenocarcinoma histology (Figure 1A and B) and undifferentiated adenocarcinoma histology (Figure $1 \mathrm{C}$ and $\mathrm{D}$ ).

Associations of TrkB at the tumour centre, TrkB at the tumour margin, and higher TrkB at the invasive front with clinicopathological variables. An ROC curve analysis was performed in the full cohort $(n=320)$ to determine the optimal cut-off values of both $\operatorname{TrkB}$ at the tumour centre and margin for discriminating patients' survival.

Patients with $>40 \%$ of TrkB positivity at the tumour centre and $>60 \%$ of TrkB positivity at the tumour margin were classified as 'high' TrkB expression, respectively. The remaining patients in each group were assigned as 'low', respectively. Accordingly, 67 patients (21\%) showed high TrkB expression at the tumour centre, whereas 48 patients (15\%) showed high TrkB expression at the tumour margin. Sixty-five patients (12\%) showed higher TrkB expression at the invasive front whose mean percentage of TrkBpositive tumour cells at the tumour margin was higher than that at the tumour centre. None had lower TrkB expression at the tumour margin than that at the tumour centre.

As shown in Table 2, high TrkB expression at the tumour centre or tumour margin, and higher TrkB expression at the invasive front were significantly associated with several aggressive tumour phenotypes such as a larger tumour size, lymphovascular invasion, advanced $\mathrm{T}$ stage, lymph node involvement, synchronous liver and peritoneal metastasis, other distant metastasis, and advanced stage, respectively.

Prognostic impact of TrkB expression status in both test and validation subgroups. Patients were divided into the test and validation subgroup according to the treatment period. Ninetyeight patients undergoing gastrectomy between 2000 and 2005 were used as the test subgroup to determine the optimal cut-off values discriminating patients' survival. The cut-off values of TrkB at the tumour centre and tumour margin were 10 and $70 \%$, respectively. The remaining patients $(n=222)$ were assigned as the validation subgroup to validate the prognostic value of $\operatorname{TrkB}$ expression status using these cut-off values.

In the test subgroup $(n=98)$, univariate survival analysis showed that $\operatorname{TrkB}$ at the tumour margin and higher $\operatorname{TrkB}$ at the invasive front were significant risk factors affecting prognosis as well as general clinicopathological variables, including depressive macroscopic morphology, advanced $\mathrm{T}$ stage, lymph node metastasis, vascular invasion, synchronous liver and peritoneal metastasis, and other distant metastasis (other than the liver and peritoneal metastasis) (Table 3 ).

In the validation subgroup $(n=222)$, univariate analysis showed $\operatorname{TrkB}$ at the tumour centre and tumour margin, and higher TrkB at the invasive front were significant risk factors affecting prognosis, respectively. However, only higher TrkB at the invasive front $(\mathrm{HR}=2.09 ; 95 \% \mathrm{CI}: 1.26-3.53 ; P<0.01)$ was retained as an independent prognostic factor as well as age, lymph node metastasis, liver, peritoneal, and other distant metastasis in multivariate analysis of the validation subgroup.

Figure 2 showed Kaplan-Meier survival analyses of the test (A) and validation (B) subgroups according to the higher TrkB expression at the invasive front.

Associations of tumour cell dedifferentiation and tumour budding with clinicopathological variables. According to the definition of tumour cell dedifferentiation in this study, 21 patients (14\%) showed both well or moderately differentiated at the surface to the centre and poorly differentiated at the margin in patients with predominantly differentiated histology $(n=153)$.

In this subgroup, the average number of tumour budding per HPF $(\times 400)$ ranged from 0 to 90 . The mean and median number of tumour budding were 20 and 13 , respectively. The optimal cutoff value of tumour budding was determined as 10 using an ROC curve analysis. Ninety-two patients (60\%) showed high-grade tumour budding ( $>10$ tumour buds per HPF).

As shown in Table 4, tumour cell dedifferentiation and tumour budding were significantly associated with several aggressive tumour phenotypes such as a larger tumour size, depressive macroscopic morphology, lymphovascular invasion, advanced T stage, lymph node involvement, synchronous liver metastasis, other distant metastasis, and advanced stage, respectively.

High-grade tumour budding was significantly associated with $\operatorname{TrkB}$ at the tumour centre, TrkB at the tumour margin, and higher TrkB at the invasive front. However, no significant association between tumour cell dedifferentiation and TrkB expression status was found.

These results suggested that high-grade tumour budding seems to be associated with aggressive tumour phenotypes or change in TrkB expression as compared with tumour cell dedifferentiation.

Prognostic impact of tumour cell dedifferentiation and tumour budding in predominantly differentiated histology. In patients with predominantly differentiated histology $(n=153)$, prognostic 


\begin{tabular}{|c|c|c|c|c|c|c|c|c|c|c|c|c|c|}
\hline \multirow[b]{3}{*}{ Variables } & \multicolumn{6}{|c|}{ Test subgroup $(n=98)$} & \multicolumn{7}{|c|}{ Validation subgroup $(n=222)$} \\
\hline & \multicolumn{3}{|c|}{ Univariate } & \multicolumn{3}{|c|}{ Multivariate } & \multirow[b]{2}{*}{ Variables } & \multicolumn{3}{|c|}{ Univariate } & \multicolumn{3}{|c|}{ Multivariate } \\
\hline & HR & $95 \% \mathrm{Cl}$ & $P$-value & HR & $95 \% \mathrm{Cl}$ & $P$-value & & HR & $95 \% \mathrm{Cl}$ & $P$-value & HR & $95 \% \mathrm{Cl}$ & $P$-value \\
\hline \multicolumn{7}{|l|}{ TrkB at the tumour centre } & \multicolumn{7}{|l|}{ TrkB at the tumour centre } \\
\hline (High vs low) & 1.08 & $0.82-1.44$ & 0.59 & & & & (High vs low) & 1.98 & $1.24-3.65$ & $<0.01$ & 1.32 & $0.71-2.74$ & 0.39 \\
\hline \multicolumn{7}{|l|}{ TrkB at the tumour margin } & \multicolumn{7}{|l|}{ TrkB at the tumour margin } \\
\hline (High vs low) & 1.49 & $1.04-2.05$ & 0.03 & 1.09 & $0.69-1.66$ & 0.69 & (High vs low) & 3.11 & $1.99-4.63$ & $<0.01$ & 1.38 & $0.78-2.37$ & 0.26 \\
\hline \multicolumn{7}{|c|}{ Higher TrkB at the invasive front } & \multicolumn{7}{|c|}{ Higher TrkB at the invasive front } \\
\hline (Positive vs negative) & 1.58 & $1.19-2.10$ & $<0.01$ & 1.24 & $0.89-1.72$ & 0.19 & (Positive vs negative) & 3.18 & $2.21-4.57$ & $<0.01$ & 2.09 & $1.26-3.53$ & $<0.01$ \\
\hline \multicolumn{7}{|l|}{ Gender } & \multicolumn{7}{|l|}{ Gender } \\
\hline (Male vs female) & 1.30 & $0.95-1.75$ & 0.09 & & & & (Male vs female) & 0.77 & $0.49-1.12$ & 0.17 & & & \\
\hline \multicolumn{7}{|l|}{ Age } & \multicolumn{7}{|l|}{ Age } \\
\hline$(>70$ vs $\leqslant 70)$ & 1.00 & $0.76-1.33$ & 0.98 & & & & $(>68$ vs $\leqslant 68)$ & 1.61 & $1.13-2.35$ & $<0.01$ & 1.83 & $1.22-2.87$ & $<0.01$ \\
\hline \multicolumn{7}{|l|}{ Tumour size } & \multicolumn{7}{|l|}{ Tumour size } \\
\hline$(>50 \mathrm{~mm}$ vs $\leqslant 50 \mathrm{~mm})$ & 1.15 & $0.86-1.57$ & 0.35 & & & & $(>35 \mathrm{~mm}$ vs $\leqslant 35 \mathrm{~mm})$ & 1.92 & $1.31-2.96$ & $<0.01$ & 0.97 & $0.53-1.82$ & 0.92 \\
\hline \multicolumn{7}{|l|}{ Macroscopic type } & \multicolumn{7}{|l|}{ Macroscopic type } \\
\hline (Depressed vs protruded) & 1.49 & $1.10-2.06$ & $<0.01$ & 1.19 & $0.85-1.71$ & 0.31 & (Depressed vs protruded) & 2.33 & $1.63-3.41$ & $<0.01$ & 1.14 & $0.68-1.93$ & 0.62 \\
\hline \multicolumn{7}{|l|}{ Histology 2} & \multicolumn{7}{|l|}{ Histology 2} \\
\hline $\begin{array}{l}\text { (Undifferentiated vs } \\
\text { differentiated) }\end{array}$ & 0.89 & $0.68-1.18$ & 0.44 & & & & $\begin{array}{l}\text { (Undifferentiated vs } \\
\text { differentiated) }\end{array}$ & 0.96 & $0.67-1.35$ & 0.82 & & & \\
\hline \multicolumn{7}{|l|}{ Histology 3} & Histology 3 & & & & & & \\
\hline (Diffuse vs intestinal) & 1.20 & $0.91-1.58$ & 0.21 & & & & (Diffuse vs intestinal) & 1.10 & $0.78-1.57$ & 0.58 & & & \\
\hline pT & & & & & & & pT & & & & & & \\
\hline$(T 3,4$ vs $T 1,2)$ & 1.99 & $1.27-3.63$ & $<0.01$ & 1.19 & $0.71-2.77$ & 0.55 & (T3, 4 vs $\mathrm{T} 1,2)$ & 2.37 & $1.62-3.62$ & $<0.01$ & 0.79 & $0.40-1.58$ & 0.49 \\
\hline $\mathrm{pN}$ & & & & & & & $\mathrm{pN}$ & & & & & & \\
\hline (Present vs absent) & 2.52 & $1.66-4.28$ & $<0.01$ & 2.45 & $1.52-4.43$ & $<0.01$ & (Present vs absent) & 2.99 & $2.00-4.77$ & $<0.01$ & 2.18 & $1.19-4.61$ & 0.01 \\
\hline Lymphatic invasion & & & & & & & Lymphatic invasion & & & & & & \\
\hline (Present vs absent) & 1.62 & $0.90-4.02$ & 0.12 & & & & (Present vs absent) & 2.08 & $1.30-3.82$ & $<0.01$ & 0.82 & $0.34-1.91$ & 0.65 \\
\hline Vascular invasion & & & & & & & Vascular invasion & & & & & & \\
\hline (Present vs absent) & 1.80 & $1.09-3.66$ & 0.02 & 0.78 & $0.42-1.69$ & 0.48 & (Present vs absent) & 2.40 & $1.65-3.70$ & $<0.01$ & 0.93 & $0.50-1.87$ & 0.83 \\
\hline Liver metastasis & & & & & & & Liver metastasis & & & & & & \\
\hline (Present vs absent) & 1.84 & $1.12-2.77$ & 0.02 & 1.34 & $0.79-2.11$ & 0.26 & (Present vs absent) & 4.54 & $2.68-7.21$ & $<0.01$ & 2.75 & $1.59-4.53$ & $<0.01$ \\
\hline Peritoneal metastasis & & & & & & & Peritoneal metastasis & & & & & & \\
\hline (Present vs absent) & 3.39 & $2.24-4.99$ & $<0.01$ & 3.19 & $1.96-5.19$ & $<0.01$ & (Present vs absent) & 3.17 & $2.07-4.68$ & $<0.01$ & 2.73 & $1.57-4.77$ & $<0.01$ \\
\hline Other distant metastasis & & & & & & & Other distant metastasis & & & & & & \\
\hline (Present vs absent) & 2.40 & $1.06-4.13$ & 0.02 & 1.42 & $0.66-2.69$ & 0.34 & (Present vs absent) & 3.29 & $1.98-5.08$ & $<0.01$ & 199 & $1.05-3.59$ & 0.03 \\
\hline
\end{tabular}

A

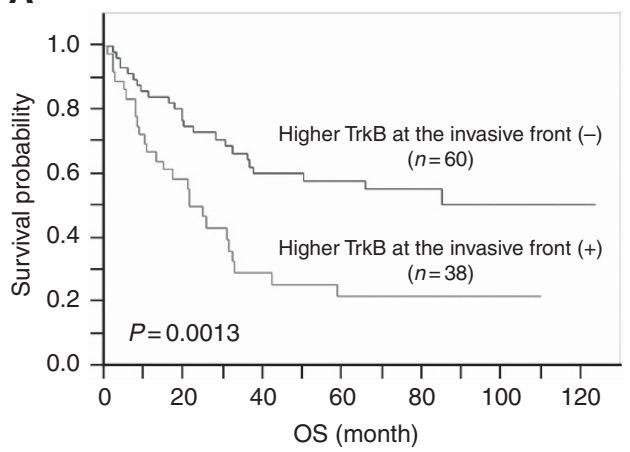

B

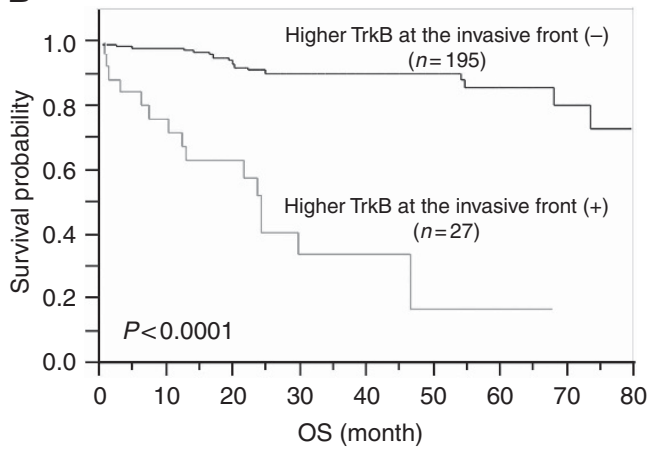

Figure 2. Kaplan-Meier analysis according to higher TrkB expression at the invasive front. In the test subgroup $(n=98, A)$, patients with higher TrkB expression at the invasive front $(n=38)$ had significantly poorer prognosis than those without it $(n=60, P=0.0013)$. In the validation subgroup $(n=222, B)$, patients with higher TrkB expression at the invasive front $(n=27)$ had significantly poorer prognosis than those without it $(n=195, P<0.0001)$. 
Table 4. Associations of tumour cell dedifferentiation and tumour budding with clinicopathological variables $(n=153)$

\begin{tabular}{|c|c|c|c|c|c|c|c|}
\hline & & \multicolumn{2}{|c|}{$\begin{array}{c}\text { Tumour cell } \\
\text { dedifferentiation }\end{array}$} & & \multicolumn{2}{|c|}{ Tumour budding } & \multirow[b]{2}{*}{$P$-value } \\
\hline Variables & Number & Absence & Presence & $P$-value & Low & High & \\
\hline \multicolumn{8}{|l|}{ Gender } \\
\hline $\begin{array}{l}\text { Male } \\
\text { Female }\end{array}$ & $\begin{array}{r}119 \\
34\end{array}$ & $\begin{array}{r}102 \\
30\end{array}$ & $\begin{array}{r}17 \\
4\end{array}$ & 0.71 & $\begin{array}{l}46 \\
15\end{array}$ & $\begin{array}{l}73 \\
19\end{array}$ & 0.57 \\
\hline \multicolumn{8}{|c|}{ Age (years) } \\
\hline $\begin{array}{l}\leqslant 70 \\
>70\end{array}$ & $\begin{array}{l}72 \\
81\end{array}$ & $\begin{array}{l}56 \\
76\end{array}$ & $\begin{array}{r}16 \\
5\end{array}$ & $<0.01$ & $\begin{array}{l}27 \\
34\end{array}$ & $\begin{array}{l}45 \\
47\end{array}$ & 0.57 \\
\hline \multicolumn{8}{|c|}{ Tumour size (mm) } \\
\hline $\begin{array}{l}\leqslant 40 \\
>40\end{array}$ & $\begin{array}{l}71 \\
82\end{array}$ & $\begin{array}{l}66 \\
66\end{array}$ & $\begin{array}{r}5 \\
16\end{array}$ & 0.02 & $\begin{array}{l}38 \\
23\end{array}$ & $\begin{array}{l}33 \\
59\end{array}$ & $<0.01$ \\
\hline
\end{tabular}

\section{Macroscopic type}

\begin{tabular}{|c|c|c|c|c|c|c|c|}
\hline 0 & 54 & 54 & 0 & & 41 & 13 & \\
\hline 1 & 16 & 14 & 2 & & 3 & 13 & \\
\hline 2 & 39 & 31 & 8 & & 8 & 31 & \\
\hline 3 & 41 & 30 & 11 & & 6 & 35 & \\
\hline 4 & 3 & 3 & 0 & $<0.01$ & 3 & 0 & $<0.01$ \\
\hline
\end{tabular}

\section{Histology 1}

Well-diff. adenoca.

Moderately diff. adenoca.

$62 \quad 61$

61
71

\begin{tabular}{r|r}
1 \\
20
\end{tabular}

$\mid$

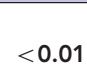

$37 \quad 25$

Lymphovascular invasion

\begin{tabular}{|l|r|r|r|r|r|r|r|}
\hline Absent & 42 & 42 & 0 & 32 & 10 & \\
Present & 111 & 90 & 21 & $<0.01$ & 29 & 82 & $<0.01$ \\
\hline
\end{tabular}

pT

\begin{tabular}{|l|l}
\hline T1 & 65 \\
\hline
\end{tabular}

T2

T4

$\mathrm{pN}$

\begin{tabular}{l|l}
65 & 63 \\
13 & 1 \\
34 & 32 \\
41 & 27
\end{tabular}

\begin{tabular}{l|r}
\hline 63 & 2 \\
11 & 2 \\
32 & 3 \\
27 & 14 \\
\hline
\end{tabular}

$<0.01$

$<0.01$

Absent

Present

84

Liver metastasis

Absent

Present

12

124
8

8

0.07

$<0.01$

50

11

\section{Peritoneal metastasis}

Absent

Present

145

Other distant metastasis

Absent

Present

145

45
8

127
5

0.08

0.08

59
2

\section{pStage}

\begin{tabular}{|c|c|c|c|c|c|c|c|}
\hline $\begin{array}{l}1 \\
2 \\
3 \\
4\end{array}$ & $\begin{array}{l}72 \\
24 \\
33 \\
24\end{array}$ & $\begin{array}{l}69 \\
22 \\
24 \\
17\end{array}$ & $\begin{array}{l}3 \\
2 \\
9 \\
7\end{array}$ & $<0.01$ & $\begin{array}{r}47 \\
8 \\
4 \\
2\end{array}$ & $\begin{array}{l}25 \\
16 \\
29 \\
22\end{array}$ & $<0.01$ \\
\hline \multicolumn{8}{|c|}{ TrkB at the tumour centre } \\
\hline $\begin{array}{l}\text { Low } \\
\text { High }\end{array}$ & $\begin{array}{l}68 \\
85\end{array}$ & $\begin{array}{l}62 \\
70\end{array}$ & $\begin{array}{r}6 \\
15\end{array}$ & 0.11 & $\begin{array}{l}35 \\
26\end{array}$ & $\begin{array}{l}33 \\
59\end{array}$ & $<0.01$ \\
\hline
\end{tabular}


Table 4. (Continued)

\begin{tabular}{|c|c|c|c|c|c|c|c|}
\hline & & \multicolumn{2}{|c|}{$\begin{array}{c}\text { Tumour cell } \\
\text { dedifferentiation }\end{array}$} & & \multicolumn{2}{|c|}{ Tumour budding } & \multirow[b]{2}{*}{$P$-value } \\
\hline Variables & Number & Absence & Presence & $P$-value & Low & High & \\
\hline \multicolumn{8}{|c|}{ TrkB at the tumour margin } \\
\hline $\begin{array}{l}\text { Low } \\
\text { High }\end{array}$ & $\begin{array}{r}123 \\
30\end{array}$ & $\begin{array}{r}109 \\
23\end{array}$ & $\begin{array}{r}14 \\
7\end{array}$ & 0.11 & $\begin{array}{r}55 \\
6\end{array}$ & $\begin{array}{l}68 \\
24\end{array}$ & 0.01 \\
\hline \multicolumn{8}{|c|}{ Higher TrkB at the invasive front } \\
\hline Absent & $\begin{array}{r}119 \\
34\end{array}$ & $\begin{array}{r}106 \\
26\end{array}$ & 13 & 7070 & $\begin{array}{r}58 \\
3\end{array}$ & 61 & $<001$ \\
\hline
\end{tabular}
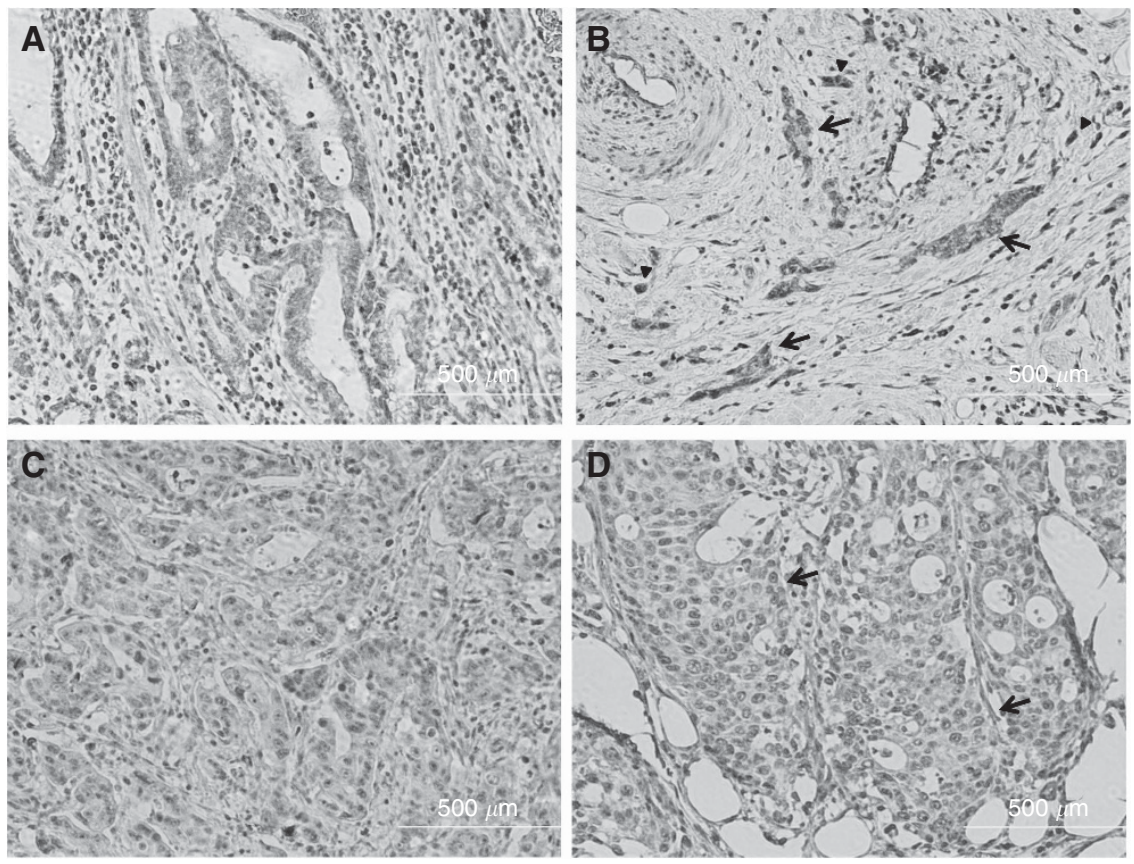

Figure 3. Higher TrkB expression in dedifferentiated tumour cells at the tumour invasive front. The representative images from two cases with higher TrkB expression in dedifferentiated tumour cells were shown. Figures ( $\mathbf{A}$ and $\mathbf{B})$ or $(\mathbf{C}$ and $\mathbf{D})$ were from the same patient. TrkB expression at the tumour margin ( $\mathbf{B}$ and $\mathbf{D}$ ) was higher than that of the tumour centre ( $\mathbf{A}$ and $\mathbf{C}$ ) in each patient. Tumour cell dedifferentiation was observed as the tumour cell cluster of more than six tumour cells with no glandular formation (arrows). Higher TrkB expression in dedifferentiated tumour cells was observed at the tumour invasive front. Higher TrkB expression in tumour budding was also observed (arrowheads).

values of tumour cell dedifferentiation and tumour budding were examined.

Univariate analysis showed that tumour cell dedifferentiation ( $\mathrm{HR}=1.65 ; 95 \% \mathrm{CI}: 1.07-2.41 ; P=0.02)$ and tumour budding $(\mathrm{HR}=1.61 ; 95 \% \mathrm{CI}: 1.12-2.41 ; P<0.01)$ were significant risk factors affecting prognosis as well as TrkB at the tumour margin $(\mathrm{HR}=1.91 ; 95 \% \mathrm{CI}: 1.33-2.67 ; P<0.01)$, higher $\mathrm{TrkB}$ at the invasive front $(\mathrm{HR}=2.02 ; 95 \% \mathrm{CI}: 1.46-2.78 ; P<0.01)$, and general clinicopathological variables, including depressive macroscopic morphology, advanced $\mathrm{T}$ stage, lymph node metastasis, vascular invasion, liver and peritoneal metastasis (Supplementary Table 1). However, neither tumour cell dedifferentiation nor tumour budding wasn't retained as independent prognostic factors in multivariate analysis. In this subgroup, only lymph node, liver, and peritoneal metastasis were identified as independent prognostic factors.

Kaplan-Meier survival analyses showed that patients with tumour cell dedifferentiation (A) or high-grade tumour budding
(B) had a significantly poorer prognosis than those without these factors (Supplementary Figure 1).

Higher TrkB expression in dedifferentiated tumour cells. Figure 3 showed representative images of two cases with higher TrkB expression in dedifferentiated tumour cells. Figures A and B or $\mathrm{C}$ and $\mathrm{D}$ were from the same patient. TrkB expression at the tumour margin (Figure $3 \mathrm{~B}$ and $\mathrm{D}$ ) was higher than that of the tumour centre (Figure 3A and C) in each patient. Tumour cell dedifferentiation was observed as the tumour cell cluster of more than five tumour cells with no glandular formation (arrows). Higher TrkB expression in dedifferentiated tumour cells was observed at the tumour invasive front. Higher TrkB expression in tumour budding was also observed (arrowheads).

Higher TrkB expression in tumour budding. Figure 4 showed representative images of two cases with higher TrkB expression in tumour budding. Figures A, C, and E or B, D, and F were from the 

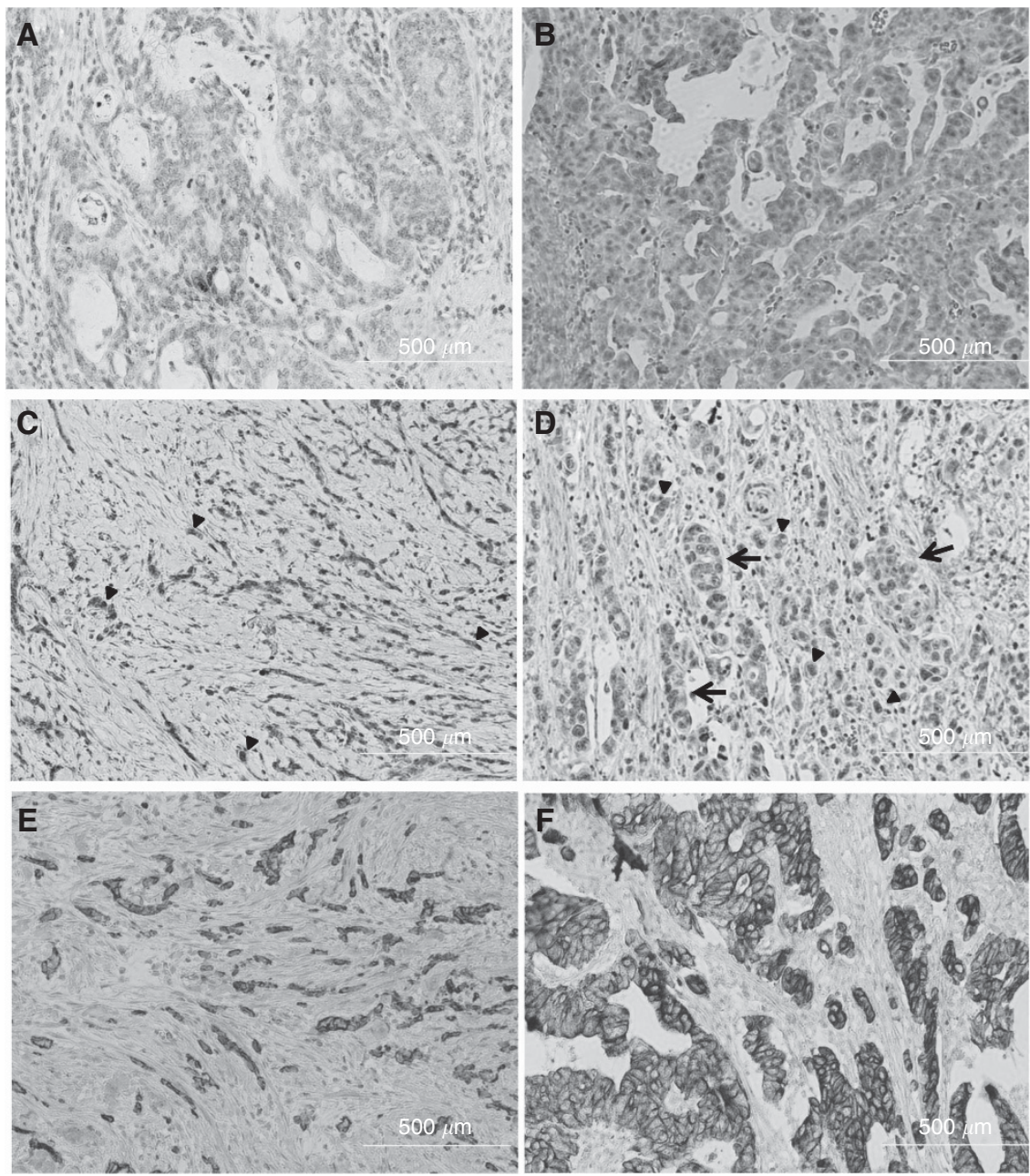

Figure 4. Higher TrkB expression in tumour budding at the tumour invasive front. The representative images of two cases with higher TrkB expression in tumour budding were shown. Figures ( $\mathbf{A}, \mathbf{C}$ and $\mathbf{E})$ or $(\mathbf{B}, \mathbf{D}$ and $\mathbf{F})$ were from the same patient. TrkB expression at the tumour margin $(\mathbf{C}$ and $\mathbf{D})$ was higher than that of the tumour centre $(\mathbf{A}$ and $\mathbf{B})$ in each patient. Figures $\mathbf{E}$ and $\mathbf{F}$ were cytokeratin-stained sections from each patient. Tumour budding was observed as an isolated single tumour cell or a tumour cluster of fewer than five tumour cells with no glandular formation. Higher TrkB expression in tumour budding was observed at the tumour invasive front (arrowheads). Higher TrkB expression in dedifferentiated tumour cells was also observed (arrows).

same patient. TrkB expression at the tumour margin (Figure $4 \mathrm{C}$ and D) was higher than that of the tumour centre (Figure $3 \mathrm{~A}$ and $\mathrm{B}$ ) in each patient. Figure $4 \mathrm{E}$ and $\mathrm{F}$ were cytokeratin-stained sections from each patient. Tumour budding was observed as an isolated single tumour cell or a tumour cluster of fewer than five tumour cells with no glandular formation. Higher TrkB expression in tumour budding was observed at the tumour invasive front (arrowheads). Higher TrkB expression in dedifferentiated tumour cells was also observed (arrows).

There was a significantly positive correlation between $\operatorname{TrkB}$ expression at the tumour margin and tumour budding $(r=0.245$, $P=0.0023)$, although no correlation was found between $\operatorname{TrkB}$ expression at the tumour centre and tumour budding $(r=0.134$, $P=0.0997)$ as shown in Supplementary Figure 2 .

These results suggested that there seemed to be a significant association between the molecular change (overexpression of TrkB) and the morphological change (tumour budding).

\section{DISCUSSION}

GCs frequently show marked histological heterogeneity and co-existence of several histological components within the tumour. We hypothesised that the mixed histological GCs having both differentiated and undifferentiated components may show a 'dedifferentiation' or 'high-grade transformation' phenotype, which is defined as a state that differentiated tumour cells change to less differentiated cells. Poorly differentiated or undifferentiated components within the differentiated GC might be considered as dedifferentiated components, or transformed cells towards a less differentiated state.

Among such mixed histological GCs showing a co-existence of dedifferentiated and original differentiated components, we focused on GCs having a predominant well/moderately differentiated component (low or intermediate grade) at the surface to the centre of the tumour accompanied by a poorly differentiated component (poorly differentiated) at the invasive front of the tumour.

We have also focused on an anoikis resistance related gene, TrkB (Douma et al, 2004), whose aberrant expression may enhance a resistance of detachment-induced apoptosis, resulting in tumour migration, invasion, and metastasis (Thiele et al, 2009; Li et al, 2011; Lee et al, 2012; Sasahira et al, 2013). In this regard, a special attention was paid on $\operatorname{TrkB}$ at the invasive front where epithelial malignant cells acquire the ability of migration or invasion and just leave from primary tumour.

In this study, higher TrkB expression at the tumour invasive front was significantly associated with aggressive tumour 
phenotypes and identified as an independent prognostic factor of GC patients. It was also significantly associated with tumour budding rather than tumour cell dedifferentiation, although there was a significant association between tumour budding and tumour cell dedifferentiation $(P<0.0001$; data not shown).

Recently, poorly differentiated component (POR), which is defined as a certain area composed of tumour clusters of more than five tumour cells with no glandular formation has been reported to show a clinical significance in colorectal cancer (Ueno et al, 2012). We also observed tumour clusters of more than five tumour cells with no glandular formation in GC patients with tumour cell dedifferentiation (Figures 3 and 4). We think that POR proposed by Ueno et al (2012) seems to be identical to tumour cell dedifferentiation, and that tumour budding might have more migratory and invasive ability than POR or tumour cell dedifferentiation. Tumour budding, but not tumour cell dedifferentiation, was significantly associated with liver and peritoneal metastasis (Table 4).

Although higher TrkB expression in both dedifferentiated tumour cells and tumour buds was observed at the tumour invasive front, their association with clinicopathological variables and clinical outcome were not clarified yet.

To examine the characteristics of tumour cells with both the molecular change such as overexpression of $\operatorname{TrkB}$ and the morphological change such as tumour budding or tumour cell dedifferentiation, immunohistochemistry using whole-tissue sections seems to be useful. The assessment of immunoreactivity for the certain protein in tumour buds using a multiple-punch tissue microarray technique has been reported (Dawson et al, 2014). Further studies will be needed to reveal the clinical and prognostic importance of molecular and morphological change of tumour cells at the invasive front of primary GC.

However, our results suggest that isolated single or clustered tumour cells (POR or tumour cell dedifferentiation) detached from the primary tumour may be regarded as anoikis-resistant cells, and may be associated with invasion, metastasis, and poor prognosis.

The evaluation of both molecular and morphological change of tumour cells at the invasive front may provide prognostic information for patients with not only GC but also other human malignancies.

In conclusion, assessment of immunoreactive TrkB at the tumour invasive front using whole-tissue sections may provide prognostic information for GC patients. Morphological and molecular characteristics of the tumour cells at the tumour-stroma interface may be associated with tumour progression of GC.

\section{ACKNOWLEDGEMENTS}

We thank Motoko Ueeda and Chihiro Hibi for providing excellent technical assistance. This work was supported in part by grants from the Ministry of Education, Culture, Sports, Science and Technology of Japan (KAKENHI 24591972 to YI and 25462051 to SS).

\section{REFERENCES}

Alpízar-Alpízar W, Christensen IJ, Santoni-Rugiu E, Skarstein A, Ovrebo K, Illemann M, Laerum OD (2012) Urokinase plasminogen activator receptor on invasive cancer cells: a prognostic factor in distal gastric adenocarcinoma. Int J Cancer 131: E329-E336.

Barbacid M (1994) The Trk family of neurotrophin receptors. J Neurobiol 25: 1386-1403.

Bosman FT, Carneiro F, Hruban RH, Theise ND (2010) WHO Classification of Tumours of the Digestive System. 4th edn. IARC Press: Lyon, France.

Brown M, Sillah K, Griffiths EA, Swindell R, West CM, Page RD, Welch IM, Pritchard SA (2010) Tumour budding and a low host inflammatory response are associated with a poor prognosis in oesophageal and gastro-oesophageal junction cancers. Histopathology 56: 893-899.
Choi JS, Kim MA, Lee HE, Lee HS, Kim WH (2009) Mucinous gastric carcinomas: clinicopathologic and molecular analyses. Cancer 115: 3581-3590.

Dahlin DC, Beabout JW (1971) Dedifferentiation of low-grade chondrosarcomas. Cancer 28: 461-466.

Dawson H, Koelzer VH, Karamitopoulou E, Economou M, Hammer C, Muller DE, Lugli A, Zlobec I (2014) The apoptotic and proliferation rate of tumour budding cells in colorectal cancer outlines a heterogeneous population of cells with various impacts on clinical outcome. Histopathology 64: 577-584.

Douma S, Van Laar T, Zevenhoven J, Meuwissen R, Van Garderen E, Peeper DS (2004) Suppression of anoikis and induction of metastasis by the neurotrophic receptor TrkB. Nature 430: 1034-1039.

Fujikawa H, Tanaka K, Toiyama Y, Saigusa S, Inoue Y, Uchida K, Kusunoki M (2012) High TrkB expression levels are associated with poor prognosis and EMT induction in colorectal cancer cells. J Gastroenterol 47: 775-784.

Horcic M, Koelzer VH, Karamitopoulou E, Terracciano L, Puppa G, Zlobec I, Lugli A (2013) Tumor budding score based on 10 high-power fields is a promising basis for a standardized prognostic scoring system in stage II colorectal cancer. Hum Pathol 44: 697-705.

Japanese Gastric Cancer Association (2011) Japanese classification of gastric carcinoma: 3rd English edn. Gastric Cancer 14: 101-112.

Karamitopoulou E, Zlobec I, Kölzer V, Kondi-Pafiti A, Patsouris ES, Gennatas K, Lugli A (2013) Proposal for a 10-high-power-fields scoring method for the assessment of tumor budding in colorectal cancer. Mod Pathol 26: 295-301.

Karamitopoulou E, Zlobec I, Panayiotides I, Patsouris ES, Peros G, Rallis G, Lapas C, Karakitsos P, Terracciano LM, Lugli A (2011) Systematic analysis of proteins from different signaling pathways in the tumor center and the invasive front of colorectal cancer. Hum Pathol 42: $1888-1896$.

Kupferman ME, Jiffar T, El-Naggar A, Yilmaz T, Zhou G, Xie T, Feng L, Wang J, Holsinger FC, Yu D, Myers JN (2010) TrkB induces EMT and has a key role in invasion of head and neck squamous cell carcinoma. Oncogene 29: 2047-2059.

LAUREN P (1965) The two histological main types of gastric carcinoma: diffuse and so-called intestinal-type carcinoma. An attempt at a histo-clinical classification. Acta Pathol Microbiol Scand 64: 31-49.

Lee J, Jiffar T, Kupferman ME (2012) A novel role for BDNF-TrkB in the regulation of chemotherapy resistance in head and neck squamous cell carcinoma. PLoS One 7: e30246.

Li Z, Oh DY, Nakamura K, Thiele CJ (2011) Perifosine-induced inhibition of Akt attenuates brain-derived neurotrophic factor/TrkB-induced chemoresistance in neuroblastoma in vivo. Cancer 117: 5412-5422.

Lugli A, Karamitopoulou E, Zlobec I (2012) Tumour budding: a promising parameter in colorectal cancer. Br J Cancer 106: 1713-1717.

McShane LM, Altman DG, Sauerbrei W, Taube SE, Gion M, Clark GM. Statistics Subcommittee of the NCI-EORTC Working Group on Cancer Diagnostics (2005) REporting recommendations for tumour MARKer prognostic studies (REMARK). Br J Cancer 93: 387-391.

Okugawa Y, Tanaka K, Inoue Y, Kawamura M, Kawamoto A, Hiro J, Saigusa S, Toiyama Y, Ohi M, Uchida K, Mohri Y, Kusunoki M (2013) Brain-derived neurotrophic factor/tropomyosin-related kinase B pathway in gastric cancer. $\mathrm{Br}$ J Cancer 108: 121-130.

Piessen G, Messager M, Leteurtre E, Jean-Pierre T, Mariette C (2009) Signet ring cell histology is an independent predictor of poor prognosis in gastric adenocarcinoma regardless of tumoral clinical presentation. Ann Surg 250: 878-887.

Sasahira T, Ueda N, Kurihara M, Matsushima S, Ohmori H, Fujii K, Bhawal UK, Yamamoto K, Kirita T, Kuniyasu H (2013) Tropomyosin receptor kinases $\mathrm{B}$ and $\mathrm{C}$ are tumor progressive and metastatic marker in colorectal carcinoma. Hum Pathol 44: 1098-1106.

Seethala RR, Hunt JL, Baloch ZW, Livolsi VA, Leon Barnes E. Adenoid cystic carcinoma with high-grade transformation: a report of 11 cases and a review of the literature (2007) Am J Surg Pathol 31: 1683-1694.

Smit MA, Peeper DS (2011) Zeb1 is required for TrkB-induced epithelialmesenchymal transition, anoikis resistance and metastasis. Oncogene 30: 3735-3744.

Sobin L, Gospodarowicz M, Wittekind C. for the International Union Against Cancer (UICC) (ed) (2009) International Union Against Cancer (UICC). 
Histopathological Grading. TNM Classification of Malignant Tumors. 7th edn. Wiley-Liss: New York, NY.

Tanaka K, Mohri Y, Nishioka J, Kobayashi M, Ohi M, Miki C, Tonouchi H, Nobori T, Kusunoki M (2009a) Neurotrophic receptor, tropomyosinrelated kinase $\mathrm{B}$ as an independent prognostic marker in gastric cancer patients. J Surg Oncol 99: 307-310.

Tanaka K, Mohri Y, Nishioka J, Ohi M, Yokoe T, Miki C, Tonouchi H, Nobori T, Kusunoki M (2009b) Neurotrophic receptor, tropomyosin-related kinase B, as a chemoresistant marker in oesophageal cancer. Clin Oncol (R Coll Radiol) 21: 362-363.

Thiele CJ, Li Z, McKee AE (2009) On Trk-the TrkB signal transduction pathway is an increasingly important target in cancer biology. Clin Cancer Res 15: 5962-5967.
Ueno H, Kajiwara Y, Shimazaki H, Shinto E, Hashiguchi Y, Nakanishi K, Maekawa K, Katsurada Y, Nakamura T, Mochizuki H, Yamamoto J, Hase K (2012) New criteria for histologic grading of colorectal cancer. Am J Surg Pathol 36: 193-201.

Zlobec I, Steele R, Terracciano L, Jass JR, Lugli A (2007) Selecting immunohistochemical cut-off scores for novel biomarkers of progression and survival in colorectal cancer. J Clin Pathol 60: $1112-1116$.

This work is published under the standard license to publish agreement. After 12 months the work will become freely available and the license terms will switch to a Creative Commons AttributionNonCommercial-Share Alike 3.0 Unported License.

Supplementary Information accompanies this paper on British Journal of Cancer website (http://www.nature.com/bjc) 